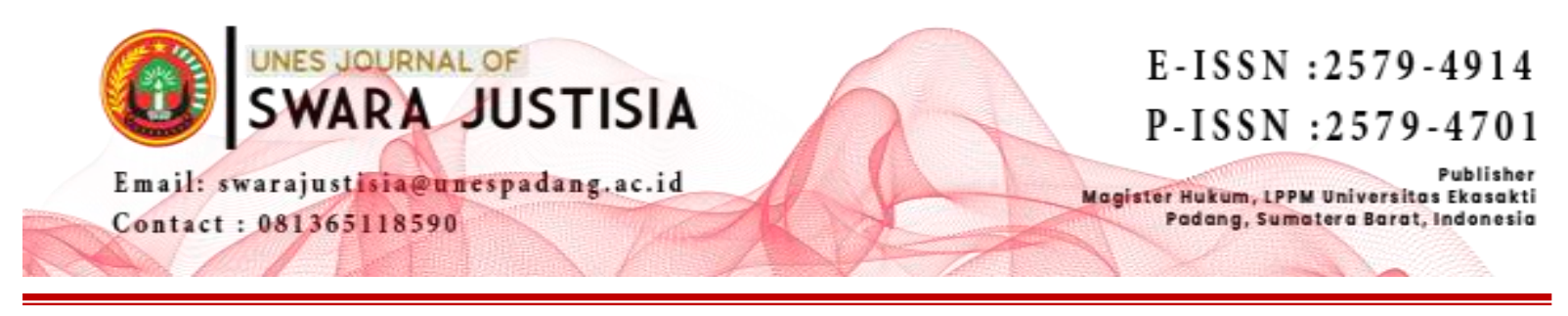

\title{
PENERAPAN KRIMINOLOGI SEBAGAI ILMU BANTU DALAM PENYIDIKAN TINDAK PIDANA YANG DILAKUKAN OLEH ANAK DI POLRES AGAM
}

\author{
${ }^{1)}$ Jukfa Hendriko, ${ }^{2)}$ Fitriati \\ 1) Program Magister Ilmu Hukum,Universitas Ekasakti, Padang \\ Email: endriko579@gmail.com \\ 2) Program Magister Ilmu Hukum,Universitas Ekasakti, Padang \\ Email: fitriati@gmail.com
}

\begin{abstract}
The application of criminology in the investigation of criminal acts committed by children by investigators at the PPA Unit of the Satreskrim Polres Agam is used to make decisions for the settlement of crimes committed by children based on examinations of the children's motivation and reasons for committing crimes. The use of criminology in investigations shows several factors that cause children to commit crimes, namely because of the influence of friends or play groups such as in the crime of motorbike theft committed by children. Another cause is the negative influence of cellphones. For example, one case of intercourse with a child by a child in Agam District, the cause is because the child often watches pornographic videos. Constraints in the application of criminology in the investigation of criminal acts committed by children by investigators at the PPA Unit of the Criminal Investigation Unit of the Agam Police are the capabilities and methods of child assistant investigators / investigators in every process of investigating child criminal acts when it is related to the various kinds of education they get as well as with facilities and infrastructure and minimal funds.
\end{abstract}

Keywords: Criminology, Investigation, Crime, Children

\begin{abstract}
ABSTRAK
Penerapan kriminologi dalam penyidikan tindak pidana yang dilakukan oleh anak oleh penyidik pada Unit PPA Satreskrim Polres Agam digunakan untuk pengambilan keputusan penyelesaian tindak pidana yang dilakukan oleh anak berdasarkan pemeriksaan motivasi dan alasan anak melakukan tindak pidana. Penggunaan kriminologi dalam penyidikan menunjukkan beberapa faktor yang menyebabkan anak melakukan tindak pidana yaitu karena pengaruh teman atau kelompok bermain seperti pada tindak pidana pencurian sepeda motor yang dilakukan oleh anak. Penyebab lainnya adalah pengaruh negatif ponsel. Misalnya salah satu kasus persetubuhan dengan anak oleh seorang anak di Kabupaten Agam, penyebabnya karena anak tersebut sering menonton video porno. Kendala dalam penerapan kriminologi dalam penyidikan tindak pidana anak oleh penyidik pada Unit PPA Bareskrim Polres Agam adalah kemampuan dan metode penyidik/penyidik pembantu anak dalam setiap proses penyidikan tindak pidana anak ketika Hal ini terkait dengan berbagai macam pendidikan yang mereka dapatkan serta dengan sarana dan prasarana serta dana yang minim.
\end{abstract}


Kata Kunci: Kriminologi, Penyidikan, Kejahatan, Anak

\section{PENDAHULUAN}

Anak merupakan bagian yang tak terpisahkan dari keberlangsungan hidup manusia dan keberlangsungan sebuah Bangsa dan Negara. Dengan peran anak yang penting ini, hak anak telah secara tegas dinyatakan dalam konstitusi, bahwa negara menjamin setiap anak berhak atas kelangsungan hidup, tumbuh dan berkembang serta berhak atas perlindungan dari kekerasan dan diskriminasi. Kepentingan terbaik bagi anak yang patut dihayati, sebagai kepentingan terbaik bagi kelangsungan hidup umat manusia. ${ }^{1}$

Perlu diketahui bahwa sebenarnya citra dan pengertian tentang manusia dan kemanusiaan merupakan faktor yang dominan dalam menghadapi dan menyelesaikan permasalahan perlindungan terhadap anak yang merupakan faktor yang dominan dalam menghadapi dan menyelesaikan permasalahan perlindungan terhadap anak yang merupakan permasalahan kehidupan manusia juga. ${ }^{2}$ Karena itu, kita semua selalu berupaya agar jangan sampai anak menjadi korban kekerasan, maupun anak terjerumus melakukan perbuatanperbuatan jahat atau perbuatan tidak terpuji lainnya. Kenakalan anak setiap tahun meningkat, oleh karena itu, berbagai upaya pencegahan dan penanggulangan kenakalan anak perlu segera dilakukan. Salah satu upaya cara pencegahan dan penanggulangan kenakalan anak (politik kriminal anak) saat ini melalui penyelenggaraan sistem peradilan anak (juvenile justice). ${ }^{3}$

Dasar hukumnya adalah Pasal 26 Undang-Undang Sistem peradilan pidana anak. Salah satu bentuk perlindungan khusus terhadap anak sebagai pelaku tindak pidana yaitu dengan membentuk Unit Pelayanan Perempuan dan Anak (PPA), yang dibentuk berdasarkan Peraturan Kapolri Nomor 10 Tahun 2007 Tentang Organisasi dan Struktur Kerja Unit Pelayanan Perempuan dan Anak di lingkungan Polri. Berdasarkan Undang-Undang ini, Unit Pelayanan Perempuan dan Anak yang selanjutnya disingkat UPPA adalah Unit yang bertugas memberikan pelayanan, dalam bentuk perlindungan terhadap perempuan dan anak yang menjadi korban kejahatan dan penegak hukum terhadap pelakunya.

Jika seorang anak melakukan tindak pidana maka ia harus diberlakukan secara khusus menurut Undang-Undang Perlindungan anak salah satunya dengan menggunakan, UndangUndang Nomor 11 Tahun 2012 tentang Sistem Peradilan Pidana Anak, bahwa dalam penanganan perkara anak wajib mengutamakan pendekatan keadilan Restoratif. Penerapan keadilan restorative dilakukan dengan terlebih dahulu mempelajari prilaku dari anak dan penyebab anak melakukan tindak pidana. Hal ini dilakukan guna pertimbangan proses dan sanksi apa yang akan diberikan pada anak. ${ }^{4}$

Berdasarkan latar belakang pemikiran di atas, maka permasalahan adalah penerapan dan kendala dalam penerapan Kriminologi sebagai ilmu bantu dalam penyidikan tindak pidana yang dilakukan anak oleh penyidik pada Unit PPA Satreskrim Polres Agam.

${ }^{1}$ Setya Wahyudi, Implementasi Ide Diversi Dalam Pembaharuan Sistem Peradilan Anak di Indonesia, Genta Publishing, Yogyakarta, 2011, hlm. 1.

${ }^{2}$ Nashrina, Perlindungan Hukum Bagi Anak di Indonesia, Rajawali Pers, Jakarta 2011, hlm. 1-2.

${ }^{3}$ Setya Wahyudi, Op., Cit., hal. 5.

${ }^{4}$ Gatot Supramono, Hukum Acara Pengadilan Anak, Djambatan, Jakarta, 2007, hlm. 38. 


\section{METODE PENELITIAN}

Spesifikasi penelitian adalah deskriptif analitis, dengan metode pendekatan yuridis normative didukung oleh yuridis empiris. Jenis data yang digunakan adalah data sekunder. Data sekunder diperoleh dari studi dokumen dan studi kepustakaan. Data yang diperoleh kemudian dianalisa secara kualitatif.

\section{PEMBAHASAN}

\section{A. Penerapan Kriminologi Dalam Penyidikan Tindak Pidana Yang Dilakukan Anak oleh penyidik pada Unit PPA Satreskrim Polres Agam}

Secara garis besar tugas-tugas penyidik ini terdiri dari tugas menjalankan operasi lapangan dan tugas administrasi hukum. Dalam melakukan penyidikan terhadap anak sebagai pelaku kejahatan seorang penyidik harus memahami Hukum Acara Pidana Anak yang ditentukan dalam Undang-Undang Nomor 11 tahun 2012 tentang peradilan Anak, karena disini tugas seorang penyidik akan dihadapkan pada hal-hal yang berhubungan dengan sisi-sisi penegakan Hak-Hak asasi Anak.

Berdasarkan pertimbangan proses penyelesaian tindak pidana yang dilakukan anak yang memiliki kekhususan daripada tindak pidana lainnya maka seorang penyidik harus dapat memanfaatkan semua ilmu bantu yang digunakan dalam penyidikan tindak pidana yang dilakukan anak, salah satunya adalah dengan menerapkan ilmu kriminologi. Meningkatnya pelanggaran hukum yang dilakukan oleh anak menyebabkan timbulnya pertanyaan tentang banyaknya anak yang melakukan tindakan melawan hukum terlebih tindakan yang dilakukan oleh anak pun beraneka ragam dan bervariasi terlebih alasan untuk melakukan tindakan melanggar hukum tersebut terbilang sangat sederhana, misalnya seorang anak melakukan penganiayaan hanya karena ingin menunjukan jati diri dan senioritas dalam pergaulan, atau melakukan perampasan atau pencurian hanya semata-mata untuk memenuhi hasratnya saja.

Dalam perbuatan anak yang berhadapan dengan hukum perlu diketahui sebabsebab timbulnya kenakalan anak atau faktor yang memicu anak melakukan kenakalan atau dengan kata lain perlu diketahui motivasinya. Bentuk dari motivasi ada 2 (dua) macam, yaitu: motivasi intrinsik dan motivasi ekstrinsik. Motivasi intrinsik merupakan dorongan atau keinginan dari dalam diri seseorang yang tidak perlu disertai perangsang dari luar, sedangkan motivasi ekstrinsik merupakan dorongan yang datang dari luar diri seseorang. ${ }^{5}$ Berikut ini akan dijabarkan mengenai 10 motivasi intrinsik dan ekstrinsik dari permasalahan anak yang berhadapan dengan hukum:

1. Yang termasuk motivasi intrinsik adalah: Faktor intelegensia, Faktor usia, Faktor kelamin, Faktor kedudukan anak dalam keluarga.

2. Yang termasuk motivasi ekstrinsik adalah: Faktor rumah tangga, Faktor pendidikan dan sekolah, Faktor pergaulan anak, Faktor mass media.

Banyaknya faktor-faktor yang menyebabkan anak melakukan kejahatan, berdasarkan hasil penelitian dengan menganalisa penggunaan kriminologi dalam penyidikan didapatkan beberapa faktor yang menyebabkan anak melakukan kejahatan di

\footnotetext{
${ }^{5}$ Nandang Sambas, Peradilan Pidana Anak di Indonesia dan Instrumen International Perlindungan Anak serta Penerapannya, Graha Ilmu, Yogyakarta, 2013, hlm 48
} 
tempat tersebut yaitu di sebabkan karena pengaruh teman atau kelompok sepermainan sudah tidak dapat kita pungkiri bahwa sekarang ini teman adalah tempat menampung segala keluh kesah. Namun, apabila salah mencari teman mereka akan menghibur dengan mencarikan solusi yang tidak baik seperti halnya hanya menuruti ajakan teman, malu untuk menolak dan diiringi oleh rasa ingin tahu yang besar seperti pada perkara Anak yang melakukan pencurian sepeda motor bersama temannya. Dimana pada saat pemeriksaan yang dilakukan terhadap anak ternyata anak tidak punya niat khusus dan tidak tahu apa tujuan pencurian motor tersebut dilakukan. Seperti keterangan anak bahwa anak pada saat itus sedang duduk di depan teras rumah anak dan datang Arif dan Sdr. Endri Pgl. Si En menggunakan 1 (satu) unit sepeda motor Honda Bled warna hitam tanpa cap body bagian depan dan singgah di tempat anak yang kemudian Sdr. Arif berkata "Pai Ang Ma Ambiak Honda" (pergi kamu mengambil honda) dan anak menjawab "yo" (ya) sambil menganggukan kepala anak kemudian anak membawa 1 (satu) unit sepeda motor Honda Scopy warna pink milik anak.

Kemudian anak dan teman teman melakukan aksi pencurian. Pengakuan anak dia bertugas melihat sekeliling dan memberi tahu jika ada orang yang lewat dan setelah 1 (satu) unit sepeda motor merk HONDA REVO FIT warna hitam nopol BA 3116 TQ, dapat dihidupkan Sdr. SI EN (panggilan) langsung yang mengendarinya. Hasil curian tersebut di bawa lari dan Sdr. ARIF Pgl. ARIF menggunakan 1 (satu) unit sepeda motor HONDA BLED warna hitam tanpa cap body bagian depan dan anak menggunakan 1 (satu) unit sepeda motor HONDA SCOPY warna pink langsung meninggalkan tempat kami melakukan pencurian. SI EN lalu memberi anak uang sejumlah Rp. 10.000,(sepuluh ribu rupiah) dan berkata kepada anak "ko untuak bali rokok" (ini untuk membeli rokok) kemudian anak berpisah dengan Sdr. ENDRI Pgl. SI EN dan Sdr. ARIF dan pulang kerumah. Anak menerangkan bahwa anak tidak tahu dimana keberadaan 1 (satu) unit sepeda motor merk HONDA REVO FIT yang dicuri tersebut.

Berdasarkan hasil pemeriksaan dapat disimpulkan bahwa anak pelaku pencurian melakukan tindak pidana tersebut hanya karena ajakan temannya atau ikut ikutan saja. Tanpa mengetahui akibat dari perbuatan tersebut. Si anak juga tidak memperoleh hasil apapun dari perbuatannya, hanya diberikan uang sejumlah Rp. 10.000,- (sepuluh ribu rupiah).

Kondisi ini sesuai dengan Dalam teori differential opportunity structure, yang mengelompokkan delinkuensi anak sebagai berikut delinkuensi adalah suatu aktivitas dengan tujuan yang pasti meraih kekayaan atau kepopuleran melalui cara-cara yang tidak sah. Delinkuensi terbentuk apabila terdapat kesenjangan Antara tujuan-tujuan yang dikehendaki secara structural diantara kaum muda (anak) dalam kesempatan-kesempatan yang terbatas dalam mencapai tujuan tujuan ini melalui cara-cara yang sah.

Kurangnya Perhatian dari Orang Tua Seorang anak pada masa modern ini sangat membutuhkan arahan, perhatian dari orang tua sangat diperlukan. Karena semakin bertambahnya umur seorang anak akan semakin membuat dia semakin ingin tahu lebih jauh tentang apa yang ingin mereka ketahui. Dengan semakin merosotnya moral dan berkembangnya teknologi dan gaya pergaulan di masa kini peranan orang tua untuk mengawasi dan membimbing anaknya semakin dibutuhkan agar anaknya tidak mengarah kepada hal-hal yang negatif. Seperti anak yang melakukan pencurian tersebut, dari 
pengakuannya menyatakan bahwa ianya tidak pernah mendapat perhatian dan ditanya keberadaannya oleh ke dua orang tuannya.

Sebagian besar kasus tindak pidana yang dilakukan anak yang terjadi di wilayah hukum Kepolisian Resort Agam disebabkan oleh kurangnya perhatian dari orang tua, karena orang tua yang sudah tidak memperhatikan anaknya dapat menyebabkan moral anaknya menjadi rusak disebabkan oleh pengaruh pengaruh dari luar yang menjerumuskannya terhadap berbagai perbuatan negatif. Pengaruh Negatif Dari Teknologi Dan Media Massa Hampir semua kalangan baik anak SD, SMP, SMA, maupun orang dewasa menggunakan handphone, memang diakui bahwa handphone memiki banyak kegunaan jika digunakan secara positif, tetapi di sisi lain handphone memiliki pengaruh negatif, Perlu diketahui bahwa anak memiliki rasa ingin tahu yang sangat besar terhadap apa yang ingin dia ketahui, penggunaan handphone hanya untuk menyimpan bahkan menonton video porno lama kelamaan akan dapat menimbulkan kejahatan dan pelakunya pastinya jangankan orang dewasa anak-anak pun dapat menjadi pelaku akibat kebiasaan menonton video porno tersebut.

Seperti salah satu kasus Persetubuhan terhadap anak yang dilakukan oleh anak di Kabupaten Agam, berdasarkan hasil wawancara terhadap seorang anggota Kepolisian Polisi Resort Kabupaten Agam modus dari pelaku beliau nekat melakukan perbuatan Persetubuhan terhadap anak karena telah sering menonton video porno yang dia tonton melalui handphone miliknya maupun dia lihat lewat situs internet. Anak melakukan perbuatan cabul dan persetubuhan terhadap seorang perempuan yang juga masih dibawah umur. Anak menerangkan Sebab Anak melakukan perbuatan cabul dan Persetubuhan Terhadap Anak Dibawah Umur yaitu karena Anak nafsu terhadap korban akibat seringnya menonton video porno. Anak menerangkan tidak mengetahui akibat yang dialami oleh korban setelah Anak melakukan perbuatan cabul dan Persetubuhan Terhadap Anak Dibawah Umur tersebut.

Putus Sekolah Kurangnya pendidikan akibat putus sekolah dapat menjadi faktor penyebab anak melakukan kejahatan, waktu anak yang sebagian besar seharusnya digunakan untuk belajar di sekolah untuk menimba ilmu harus terbengkalai akibat putus sekolah. Masih banyaknya anak putus sekolah di wilayah hukum Polres Agam, mereka hanya berpendidikan sampai SMA dan bahkan SMP. Anak putus sekolah baik karena orang tuanya yang tidak mampu untuk menyekolahkan anaknya karena tidak memiliki uang atau karena anak itu sendiri yang sudah tidak ingin. Waktu yang di habiskan anak yang tidak sekolah untuk berkeliaran di jalan dapat menimbulkan pengaruh negatif pada dirinya, pengaruh itu bisa berasal dari temannya ataupun dari orang lain.

Moral dan Akhlak Yang Semakin Menurun Kemerosotan moral dan akhlak yang terjadi pada anak dapat menyebabkan anak melakukan tindakan-tindakan yang negatif, termasuk melakukan kejahatan. Kemorosotan akhlak terjadi akibat kurangnya pemahaman terhadap agama, Minimnya pengetahuan tentang agama mengakibatkan anak bertingkah laku sesuka hati tanpa ada hal yang harus mengekang kegiatan yang mereka lakukan.

Pada pengunaan ilmu krimonologi juga dilakukan kunjungan rumah kepada keluarga anak tersebut, tanpa menunggu permintaan. Apa yang dipelajari dan didapatkan pada waktu kunjungan rumah itu adalah hakikat sampai terjadinya tindak pidana 
tersebut, seperti kenakalan yang pernah dilakukan sebelumnya, latar belakang keluarganya, dengan menganalisa masing-masing anggota keluarganya, pendidikan, kondisi ekonomi, pekerjaan, keadaan rumah dan nilai-nilai yang dianut oleh keluarga tersebut, termasuk status kesehatan anak dalam keluarga. Dalam sejarah perkembangan anak dilihat hubungannya dengan orang tua, dengan kakak dan adiknya, tetangganya, dasar kepribadiannya, tingkah lakunya, dampak fisik dan emosional dari penyakitnya, pengalamannya dalam bidang keagamaan dan sekolah, data tentang pekerjaannya, kegiatan rekreasi dan pandangannya terhadap masa depan.

\section{B. Kendala Dalam Penerapan Kriminologi Dalam Penyidikan Tindak Pidana Yang Dilakukan Anak Oleh Penyidik Pada Unit PPA Satreskrim Polres Agam}

Berbagai kendala dalam penerapan ilmu kriminologi pada penyidikan tindak pidana yang dilakukan oleh anak diantaranya adalah tentang kualitas atau kemampuan penegak hukum yang diharapkan oleh masyarakat. Dari hasil penelitian dan pengamatan tindakan dan perilaku penyidik/penyidik pembantu dalam pelaksanaan penyidikan tindak pidana anak di Polres Agam dapat dijelaskan bahwa dengan melihat kemampuan dan cara kerja penyidik/penyidik pembantu anak dalam setiap proses penyidikan tindak pidana anak bila dikaitkan dengan pendidikan yang beraneka ragam mereka peroleh serta dengan sarana, prasarana dan dana yang minimal, ditambah lagi dengan tidak dapat terpenuhinya persyaratan sebagai penyidik anak, maka penyidikan tindak pidana anak sebagaimana diharapkan masyarakat untuk bertindak profesional efektif, efisien, profesional dan modern belum dapat diwujudkan oleh penyidik/penyidik pembantu anak.

Penyidik/penyidik pembantu anak yang melakukan penyidikan tindak pidana anak sampai saat ini belum pernah ada pendidikan kejuruan di bidang anak maupun pemberian pengetahuan hukum acara pidana anak sebagaimana yang dimaksud dalam Undang-Undang Nomor 11 Tahun 2012 tentang Sistem Peradilan Pengadilan Anak. Pendidikan kejuruan yang diberikan kepada penyidik/penyidik pembantu khususnya di bidang anak diharapkan dapat diterapkan oleh penyidik anak dalam melakukan penyidikan anak secara baik dan benar tanpa ada lagi pelanggaran terhadap anak. Dengan demikian, pendidikan kejuruan khusus anak diharapkan dapat meningkatkan kemampuan penyidik/penyidik pembantu pidana anak dalam melaksanakan penyidikan tindak pidana anak.

Jumlah penyidik/penyidik pembantu anak juga turut mempengaruhi tindakan dan perilaku penyidik/penyidik pembantu dalam penyidikan tindak pidana anak. Dengan jumlah penyidik/penyidik pembantu yang cukup diharapkan dapat memberikan pelayanan, pengayoman dan perlindungan terhadap masyarakat dengan cepat dan baik sebagaimana yang diharapkan masyarakat. Bila menurut pemeriksaan dengan menggunakan ilmu kriminologi, penyidik anak berpendapat bahwa anak tersebut masih dapat dibina oleh orang tuanya maka penyidik anak akan menyerahkan anak tersebut kepada orang tuanya. Begitu juga misalnya jika hasil dari pemeriksaan bahwa anak tersebut tidak dapat dibina lagi maka penyidik anak akan menyerahkan kepada negara setelah mendengar pertimbangan dan saran dari pembimbing kemasyarakatan.

Pemberian motivasi kepada penyidik/penyidik pembantu anak turut mempengaruhi tindakan dan perilaku penyidik/penyidik pembantu tersebut dalam 
penyidikan tindak pidana anak. Pemberian motivasi kerja kepada para penyidik/penyidik pembantu banyak ditentukan oleh peranan pimpinan. Dalam hal memberi motivasi, seorang pemimpin tidak hanya semata-mata memacu dan memberikan semangat semata tetapi dari sisi lain juga harus diperhatikan tentang kebutuhan dan kehidupan pribadi para personilnya. Hal ini merupakan suatu terobosan agar, permasalahan yang ada pada diri penyidik/penyidik pembantu tidak larut dalam penyidikan tindak pidana anak. Faktor mental penyidik/penyidik pembantu juga ikut mempengaruhi tindakan dan perilaku penyidik/penyidik pembantu anak dalam proses penyidikan tindak pidana anak. Mental penyidik/penyidik pembantu anak yang tangguh memegang peranan penting dalam proses penyidikan tindak pidana anak. Meskipun faktor-faktor yang mempengaruhi lainnya dapat diatasi tanpa didukung dengan mental yang tangguh terdapat kecenderungan akan terjadi tindakan-tindakan atau perilaku yang menyimpang. Hal ini dapat diyakini karena seorang penyidik/penyidik pembantu bukanlah benda mati yang hidup yang setiap hari dapat berubah dan terpengaruh oleh situasi dan kondisi yang dihadapinya, khususnya dalam pemenuhan kebutuhannya. Selain itu faktor ekonomi penyidik/penyidik pembantu anak juga sangat mempengaruhi jalannya setiap proses penyidikan yang dilakukan oleh penyidik anak. Bilamana situasi ekonomi di rumah dalam keadaan tenang dan masih dapat diatasi maka tindakan penyidik anak biasanya masih dapat dikendalikan. Selain itu tindakan yang dilakukan penyidik diharapkan juga tidak dapat melukai perasaan apalagi melakukan tindakan yang bersifat melawan hukum.

Untuk penyidik anak, Kepolisian Resor Agam belum memiliki penyidik dengan keahlian khusus seperti yang dimaksudkan dalam Undang-Undang No. 11 Tahun 2012, tentang peradilan Anak, dan apabila terjadi tindak pidana yang melibatkan anak-anak sebagai pelakunya, untuk proses penyidikannya masih dilakukan oleh penyidik tindak pidana umum namun tetap mengikuti ketentuan-ketentuan yang telah ditetapkan dalam Undang-undang Nomor 11 Tahun 2012 tentang Sistem Peradilan Pidana Anak. Kemudian menyangkut keterbatasan personil, Kepolisian Resor Agam hanya memiliki satu orang penyidik Polisi wanita dan itupun belum mempunyai keahlian khusus untuk melakukan penyidikan terhadap anak-anak. Menyiasati dalam hal keterbatasan personil terutama penyidik yang memiliki keahlian khusus untuk penyidikan anak, Kepolisian Resor Agam selalu berkoordinasi dengan Unit Ruang Pelayanan Khusus (RPK) Polda Sumbar apabila menangani pelaku kejahatan / tindak pidana yang masih berstatus anakanak.

\section{PENUTUP}

Faktor mental penyidik/penyidik pembantu juga ikut mempengaruhi tindakan dan perilaku penyidik/penyidik pembantu anak dalam proses penyidikan tindak pidana anak. Mental penyidik/penyidik pembantu anak yang tangguh memegang peranan penting dalam proses penyidikan tindak pidana anak sehingga dapat menerapkan ilmu kriminologi secara tepat. Agar dapat meningkatkan kualitas profesional dari pejabat penyidikan sehingga dalam pelaksanaan tugasnya dapat lebih efesien dan efektif dengan meningkatkan standar pendidikan baik secara formal maupun informal. 


\section{REFERENSI}

Gatot Supramono, Hukum Acara Pengadilan Anak, Djambatan, Jakarta, 2007

Setya Wahyudi, Implementasi Ide Diversi Dalam Pembaharuan Sistem Peradilan Anak di Indonesia, Genta Publishing, Yogyakarta, 2011

Nashrina, Perlindungan Hukum Bagi Anak di Indonesia, Rajawali Pers, Jakarta 2011

Nandang Sambas, Peradilan Pidana Anak di Indonesia dan Instrumen International Perlindungan Anak serta Penerapannya, Graha Ilmu, Yogyakarta, 2013

Undang-Undang Nomor 11 Tahun 2012 tentang Sistem Peradilan Pidana Anak 